\title{
Kliniğimizde invaziv prenatal tanı yöntemi olarak amniyosentez uygulanan olguların retrospektif değerlendirilmesi
}

\author{
Retrospective analysis of cases undergoing amniocentesis as an invasive prenatal \\ diagnosis method in our university clinic
}

Soner Gök, Berfin Can Gök, Gökhan Ozan Çetin

Gönderilme tarihi: 15.09 .2020

Kabul tarihi: 03.12.2020

Özet

Amaç: Kadın Hastalıkları ve Doğum kliniğimizde çeşitli endikasyonlarla gerçekleştirilen genetik amniyosentez olgularından elde edilen sonuçları değerlendirmeyi amaçlamaktayız.

Gereç ve yöntem: Çalışmamızda Kasım 2018-Ağustos 2020 tarihleri arasında kliniğimize prenatal tanı değerlendirmesi nedeniyle başvurup amniyosentez uygulanan olgular dahil edilerek, olguların demografik verileri, amniyosentez endikasyonları ve sonuçları retrospektif olarak değerlendirilerek özetlendi.

Bulgular: Değerlendirmeye alınan 246 olgunun ortanca yaşı 34 (IQR:10), ortanca gebelik haftası 17 (IQR:3), ortanca gravide 3 (IQR:2), ortanca parite 1 (IQR:1), ortalama abortus sayısı 0,6 (SD:0,96) idi. Amniyosentez endikasyonları olan risk faktörleri değerlendirildiğinde 146 hastada $(\% 59,3)$ 1. trimester kombine testinde anormallik, 39 hastada $(\% 15,9) \quad 3^{\prime}$ lü tarama testinde anormallik, 14 hastada $(\% 5,7)$ 4'lü tarama testinde anormallik, 24 hastada $(\% 9,8)$ anormal USG bulgusu, 6 hastada $(\% 2,4)$ ileri anne yaşı saptanırken, 17 hastada $(\% 6,9)$ diğer risk faktörleri mevcuttu. Olguların \%4,5'inde amniyosentez anormal olarak sonuçlandı. 128 hastada (\%52) 46 XX, 107 hastada (\%43,5) 46 XY ile normal olarak sonuçlandı. Anormal olarak sonuçlanan 10 olgudan 5'inde (\%2) $47 X X+21,3$ hastada $(\% 1,2) 47 X Y+21,1$ hastada $(\% 0,4) 47 X X+13,1$ hastada $(\% 0,4) 47 X X Y$ olarak sayısal anomali saptanırken 1 hastada 46 XXt (6;13) (p23;q13) yapısal anomali saptandı. Kromozomal anomali saptanan olgularda ortanca anne yaşı $34(\mathrm{IQR}=8)$, ortanca gebelik haftası $18(\mathrm{IQR}=3)$, ortanca gravide $2,5(\mathrm{IQR}=2)$, ortanca parite ise $1(\mathrm{IQR}=1)$ idi.

Sonuç: Çalışmamızda amniyosentez endikasyonu oluşturan en sık risk faktörü maternal tarama testlerinde anormallik iken anormal USG bulgusu daha genç hastalarda endikasyon oluşturmaktaydı.

Anahtar kelimeler: Amniyosentez, kromozomal anomali, prenatal tanı.

Soner Gök S, Can Gök B, Çetin GO. Kliniğimizde invaziv prenatal tanı yöntemi olarak amniyosentez uygulanan olguların retrospektif değerlendirilmesi. Pam Tıp Derg 2021;14:215-221.

\begin{abstract}
Purpose: We aim to evaluate the results obtained from genetic amniocentesis cases performed with various indications at our Gynecology and Obstetrics clinic.

Materials and methods: In our study, cases who applied to our clinic for prenatal diagnosis evaluation between November 2018 and August 2020 and underwent amniocentesis were included. The demographic data, amniocentesis indications and results of the cases were retrospectively evaluated and summarized.

Results: Of the 246 cases evaluated; Median age was 34 (IQR:10), median gestational week was 17 (IQR:3), median gravity was 3 (IQR:2), median parity was 1 (IQR:1), mean number of abortions was 0.6 (SD:0.96). Risk factors that are indications for amniocentesis were evaluated. $146(59.3 \%)$ patients had an abnormality in the first trimester combined test, $39(15.9 \%)$ patients had an abnormality in the triple screen test, $14(5.7 \%)$ patients had an abnormality in the quadruple screening test, $24(9.8 \%)$ patients had abnormal USG findings, 6 $(2.4 \%)$ patients had advanced maternal age, and 17 (6.9\%) patients had other risk factors. Amniocentesis was abnormal in $4.5 \%$ of the cases. It was normal in $128(52 \%)$ patients with $46 \mathrm{XX}$, and $107(43.5 \%)$ patients with $46 \mathrm{XY}$. In 5 out of 10 cases $(2 \%)$ in abnormal results $47 X X+21,3$ patients $(1.2 \%) 47 X Y+21,1$ patient $(0.4 \%)$ $47 X X+13$, 1 patient $(0.4 \%)$. While numerical abnormality was detected as $47 X X Y$, a structural abnormality was found as $46 \mathrm{XXt}(6 ; 13)$ (p23;q13) in 1 patient. In cases with chromosomal anomalies, the median maternal age was $34(\mathrm{IQR}=8)$, median gestational week was $18(\mathrm{IQR}=3)$, median gravity was $2.5(\mathrm{IQR}=2)$, and median parity was $1(\mathrm{IQR}=1)$.

Conclusion: In our study, the most common risk factor for amniocentesis indication was an abnormality in maternal screening tests, while abnormal USG findings were indicative in younger patients.
\end{abstract}

Soner Gök, Dr. Öğr. Üye. Pamukkale Üniversitesi Tıp Fakültesi, Kadın Hastalıkları ve Doğum Anabilim Dalı, Denizli, Türkiye, e-posta: sonerrgok@hotmail.com (orcid.org/0000-0001-8940-1879) (Sorumlu Yazar)

Berfin Can Gök, Uzm. Dr. Servergazi Devlet Hastanesi, Kadın Hastalıkları ve Doğum Kliniği, Denizli, Türkiye, e-posta: berfinyurdam@gmail. com (orcid.org/0000-0001-5739-3683)

Gökhan Ozan Çetin, Doç. Dr. Pamukkale Üniversitesi Tıp Fakültesi, Tıbbi Genetik Anabilim Dalı, Denizli, Türkiye, e-posta: ocetin@pau.edu.tr (orcid.org/0000-0002-6100-7973) 
Key words: Amniocentesis, chromosomal abnormality, prenatal diagnosis.

Soner Gok S, Can Gok B, Cetin GO. Retrospective analysis of cases undergoing amniocentesis as an invasive prenatal diagnosis method in our university clinic. Pam Med J 2021;14:215-221.

\section{Giriş}

Beksaç'a göre prenatal tanı, yaşam beklentisi az, tedavisinin mümkün olmadığı, ağır engellere sebep olabilen hastalıklar için yüksek riskli ebeveynlere güvence verebilmek olarak ifade edilmiştir [1]. Prenatal tanıyı mümkün kılan genetik incelemelerin ilerlemesi ile klinisyenler prenatal tanıda önemli aşama kaydetmişlerdir. Uygun gebelik takibi, aileye danışmanlık ve gebeliğin terminasyonu için günümüzde çeşitli endikasyonlar ile gerçekleştirilen amniyosentez (AS) işlemi, bu konuda en sık kullanımına başvurulan invaziv tekniktir [2, 3]. Koryon villus örneklemesi ve kordosentez de kullanılan diğer invaziv prenatal tanı yöntemleri arasındadır.

Çeşitli endikasyonları olmakla birlikte ACOG (American College of Obstetricians and Gynecologists)'a göre AS endikasyonlarını genel olarak ileri anne-baba yaşı, habitüel abortus, kromozomal anomalili veya nöral tüp defektli çocuk öyküsü, koryonvillüs örneklemesinde mozaisizm, tarama testlerinde risk yüksekliği, anormal fetal ultrasonografi (USG) bulguları, maternal anksiyete, biyokimyasal testler, fetal enfeksiyonlar, fetal durumun belirlenmesi ve fetal tedavidir [4].

$\mathrm{Bu}$ çalışmamızda kliniğimizde çeşitli endikasyonlarla gerçekleştirilen genetik amniyosentez olgularından elde edilen sonuçları değerlendirerek literatüre katkı sağlamayı amaçlamaktayız.

\section{Gereç ve yöntem}

Çalışmamız Kasım 2018-Ağustos 2020 tarihleri arasında tek merkez olarak Kadın Hastalıkları ve Doğum Kliniğimiz'e prenatal tanı değerlendirmesi nedeniyle başvurup amniyosentez uygulanan tüm olgular dahil edildi. Geriye dönük olarak taranarak tüm olguların yaşları, kan grupları, gravida sayıları, parite sayıları, abortus sayıları, önceki doğum şekilleri, amniyosentezin yapıldığı gebelik haftası, amniyosentez yapılmasına neden olan risk faktörleri, amniyosentez endikasyonları ve amniyosentez sonuçlarına işlem kayıt defterleri, HBYS sistemi ve genetik laboratuvarından ulaşıldı. Veri eksikliği ve kültür başarısızlığı çalışma dışı bırakılma kriteri olarak belirlendi.

Amniyosentez endikasyonları olarak pozitif 1. trimester kombine testi, pozitif üçlü test, pozitif dörtlü test, ileri anne yaşı ( $>35$ yaş olarak belirlendi), obstetrik ultrasonda fetal anomali görülmesi (koroid pleksus kisti, tek umblikal arter, erken hafta oligohidroamnioz, erken hafta intrauterin gelişme geriliği, artmış nukal fold kalınlığı, piyelektazi, erken hafta polihidroamnios, ventrikülomegali, hiperekojen barsak, hiperekojen kardiyak odak) ve diğer (ailede down veya turner sendromu görülmesi, önceki çocukta zihinsel engel olması, ailede genetik geçişli hastalıkların varlığı ve maternal anksiyete) olarak gruplandırıldı. Pozitif 1. trimester kombine, üçlü ve dörtlü maternal serum tarama testi trizomi 18 ve 21 için yüksek risk taşıyan gebeleri (hesaplanan kombine risk trizomi 21 için $\geq 1 / 270$, trizomi 18 için $\geq 1 / 100$ ) kapsamaktadır. Gruplandırmada ileri anne yaşı grubunu yaşı ileri olup hiçbir tarama testi yapılmadan direkt amniyosentez yapılanları içermektedir. İleri anne yaşına sahip olup tarama testinde riskli bulunanlar ise ilgili tarama testleri gruplarında değerlendirilmiştir.

Kliniğimizde girişim öncesi genetik amniyosentez girişimini kabul eden tüm gebelerden bilgilendirilmiş onam alınmaktadır. İşlem öncesi tüm gebelere Rh uyuşmazlığı için tarama yapıldı. Amniyosentez işlemi için Voluson S10 ultrason cihazı ve C1-5 RS transabdominal prob kullanılmıştır. Cilt temizliği polividon iyot ile yapılarak ponksiyon ve aspirasyon amacı ile tek kullanımlık 2 ve 20 ml'lik enjektörler ve 20 veya $22 \mathrm{G}$ spinal iğneleri kullanılmıştır. Girişimler ultrason eşliğinde "serbest el tekniği" ile yapılmıştır. İlk aspire edilen 2 ml'lik amniyon sıvısı maternal kontaminasyon açısından ayrılmıştır. Daha sonra gelen amniyon sıvısı hafif negatif basınç uygulanıp aspire edilerek, gebelik haftası başına $1 \mathrm{ml}$ olacak şekilde 20 ml'lik enjektöre toplanmıştır. Amniyon sıvısı elde edebilmek için en fazla üç deneme yapılmıştır. İşlem sonrası hastalar 1 saat klinikte gözlem altında tutulmuştur. İşlem uygulanan tüm gebelere işlem sonrası kullanılmak üzere oral 
antibiyotik (Amoksisilin $875 \mathrm{mg}, 3$ gün) ve parasetamol reçete edilmiştir.

Alınan örnekler genetik laboratuvarına gönderilmiş, 15-20 günlük hücre kültürünü takiben en az 20 metafaz görüntüsü elde edilebilen örnekler incelenmiştir.

İstatistiksel analiz Windows için SPSS v26.0 (IBM, Chicago, USA®) paket programı kullanılarak yapıldı. Verilerin dağılımı ortalama ile standard sapma veya ortanca ile çeyrekler arası aralık (IQR="interquartile range") olarak belirlendi. Kategorik değişkenler ise sayı ve yüzde olarak belirlendi. İkili gruplar arasındaki sayısal verilerin kıyaslanmasında normal dağılımlı grup karşılaştırmalarında Student $\mathrm{t}$ testi, normal olmayan dağılımlı grup karşılaştırmalarında Mann-Whitney $U$ testi kullanıldı. Nominal ve ordinal değişkenler ki kare bağımsızık testi ile karşılaştırıldı. İkiden fazla bağımsız grubun karşılaştırımasında Kruskal Wallis testi, ikiden fazla bağımlı grubun karşılaştırımasında Friedman testi kullanıldı. Gruplar arasında anlamlı fark saptanması halinde farkın hangi grup veya gruplardan kaynaklandığı Tukey ve Bonferroni testleri kullanılarak post-hoc analizi ile değerlendirildi. Tüm istatistiksel incelemelerde $p$ değeri $<0,05$ anlamlı kabul edildi.

Çalışmamı Pamukkale Üniversitesi Girişimsel Olmayan Araştırmalar Etik Kurulu onayının alınması sonrasında başlatıımıştır.

\section{Bulgular}

Çalışmaya Kasım 2018-Ağustos 2020 tarihleri arasında Kadın Hastalıkları ve Doğum Kliniği'nde uygulanan toplam 256 amniyosentez işlemi dahil edildi. 10 işlem veri eksikliği veya kültür başarısızlığı nedeniyle çalışma dışı bırakıldı.

Değerlendirmeye alınan 246 olgunun ortanca yaşı 34 (IQR:10, min:17, maks:43), ortanca gebelik haftası 17 (IQR:3, min: 16, maks:21), ortanca gravide 3 (IQR:2, min:1, maks:9), ortanca parite 1 (IQR:1, min:0, maks:5), ortalama abortus sayısı 0,6 (SD:0,96, min:0, maks:7) idi (Tablo 1).

Tablo 1. Olguların demografik verilerinin değerlendirilmesi

\begin{tabular}{lllll}
\hline & Normal & Anormal & Toplam & p \\
\hline Hasta sayısI, n (\%) & $236(96)$ & $10(4)$ & $246(100)$ & \\
Yaş, ortanca (IQR) & $34(10)$ & $34(8)$ & $34(10)$ & 0,913 \\
GH, ortanca (IQR) & $17(3)$ & $18(3)$ & $17(3)$ & 0,179 \\
Gravide, ortanca (IQR) & $3(2)$ & $2,5(2)$ & $3(2)$ & 0,862 \\
Parite, ortanca (IQR) & $1(1)$ & $1(1)$ & $1(1)$ & 0,735 \\
\hline
\end{tabular}

IQR: Çeyrekler arası aralık, Min: Minimum, Max: Maksimum, GH: Gebelik haftası

Olguların kan grupları sıklık sırasıyla 106 hastada $(\% 43,1) \mathrm{A} \mathrm{Rh+,}, 68$ hastada $(\% 27,6) 0$ $\mathrm{Rh}+, 35$ hastada $(\% 14,2) \mathrm{B} \mathrm{Rh+,} 16$ hastada $(\% 6,5) \mathrm{AB} \mathrm{Rh}+, 9$ hastada $(\% 3,7) 0 \mathrm{Rh}-, 7$ hastada $(\% 2,8)$ A Rh-, 4 hastada $(\% 1,6)$ B Rh-, 1 hastada da $(\% 0,4)$ AB Rh- olarak saptandı.

Olguların önceki doğum şekli 90 hastada $(\% 36,6)$ normal spontan vajinal doğum (NSVD), 78 hastada $(\% 31,7)$ sezaryen sectio (C/S), 20 hastada $(\% 8,1)$ hem NSVY hem de C/S ile gerçekleşmişken 58 hastada $(\% 23,6)$ doğum öyküsü bulunmamaktaydı.

Amniyosentez endikasyonları olan risk faktörleri değerlendirildiğinde 146 hastada $(\% 59,3)$ 1. trimester kombine testinde anormallik, 39 hastada $(\% 15,9)$ 3'lü tarama testinde anormallik, 14 hastada $(\% 5,7)$ 4'lü tarama testinde anormallik, 24 hastada $(\% 9,8)$ anormal USG bulgusu, 6 hastada $(\% 2,4)$ ileri anne yaşı saptanırken, 17 hastada $(\% 6,9)$ diğer risk faktörleri mevcuttu (Şekil 1).

Anormal USG bulgusu olan hastalar değerlendirdiğinde 24 gebenin 5 'inde $(\% 20,8)$ tek umblikal arter, 8 'inde $(\% 33,3)$ artmış nukal fold kalınlığı, 6'sında (\%25) hiperekojen barsak ve 5 'inde $(\% 20,8)$ hiperekojen kardiyak odak saptanması nedeniyle amniyosentez işlemi uygulandı. 


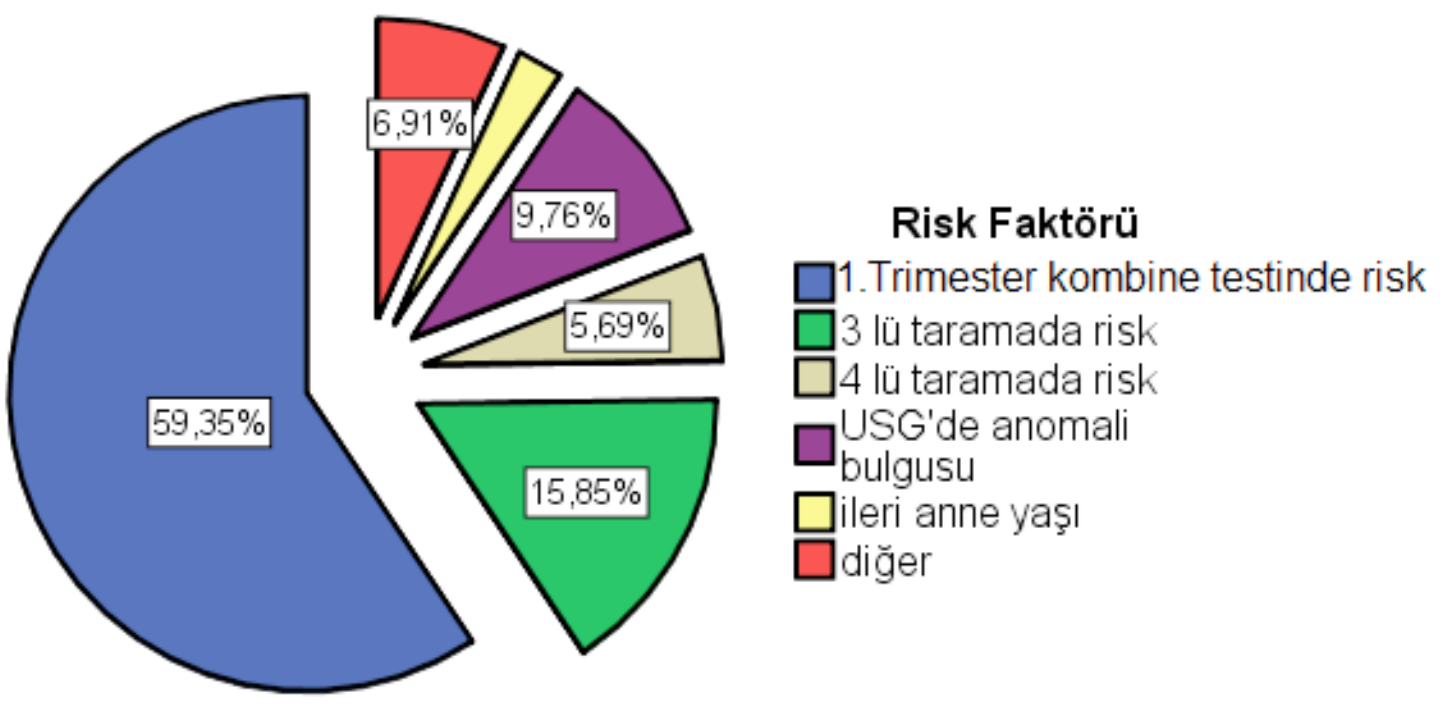

Şekil 1. Amniyosentez endikasyonu oluşturan risk faktörleri

Olguların \%95,5'inde amniyosentez normal karyotipte, $\% 4,5$ 'i ise anormal olarak sonuçlandı. 128 hastada (\%52) 46 XX, 107 hastada $(\% 43,5)$ $46 \mathrm{XY}$ ile normal olarak sonuçlandı. Anormal olarak sonuçlanan 10 olgudan 5 'inde (\%2) 47 $X X+21,3$ hastada $(\% 1,2) 47 X Y+21,1$ hastada $(\% 0,4) 47 X X+13,1$ hastada $(\% 0,4) 47 \mathrm{XXY}$ olarak sayısal anomali saptanırken 1 hastada 46 $X X, t(6 ; 13)(p 23 ; q 13)$ yapısal anomali saptandı (Tablo 2), (Şekil 2).
Amniyosentez endikasyonu olarak 1 . trimester kombine testinde anormallik olan 146 hastanın 7 'sinde $(\% 4,7)$, 3'lü tarama testinde anormallik olan 39 hastanın 1'inde (\%2,5), 4'lü tarama testinde anormallik olan 14 hastanın 1 'inde $(\% 7,1)$ ve anormal USG bulgusu olan 24 hastanın ise 1 'inde $(\% 4,1)$ anormal sonuç saptandı (Tablo 3). Anormal USG sonucu olarak artmış nukal fold kalınlığı nedeniyle yapılan amniyosentez sonucu trizomi 21 tespit edilmiştir.

Tablo 2. Amniyosentez sonuçlarına göre demografik verilerin değerlendirilmesi

\begin{tabular}{llllllll}
\hline & $\mathbf{4 6} \mathbf{X X}$ & $\mathbf{4 6} \mathbf{X Y}$ & $\mathbf{4 7} \mathbf{X X + 2 1}$ & $\mathbf{4 7} \mathbf{X Y + 2 1}$ & $\mathbf{4 7} \mathbf{X X + 1 3}$ & $\mathbf{4 7} \mathbf{X X Y}$ & $\boldsymbol{p}$ \\
\hline Hasta sayısI, n (\%) & $128(52)$ & $107(43,5)$ & $5(2)$ & $3(1,2)$ & $1(0,4)$ & $1(0,4)$ & \\
Yaş, ortanca (IQR) & $34(10)$ & $33(9)$ & $30(8)$ & 34 & 40 & 39 & 0,322 \\
GH, ortanca (IQR) & $17(3)$ & $17(3)$ & $20(4)$ & 1 & 18 & 17 & 0,498 \\
Gravide, ortanca (IQR) & $3(2)$ & $2(3)$ & $2(2)$ & 2 & 3 & 4 & 0,83 \\
Parite, ortanca (IQR) & $1(1)$ & $1(2)$ & $1(2)$ & 1 & 1 & 2 & 0,68 \\
\hline
\end{tabular}

IQR: Çeyrekler arası aralık, GH: Gebelik haftası 


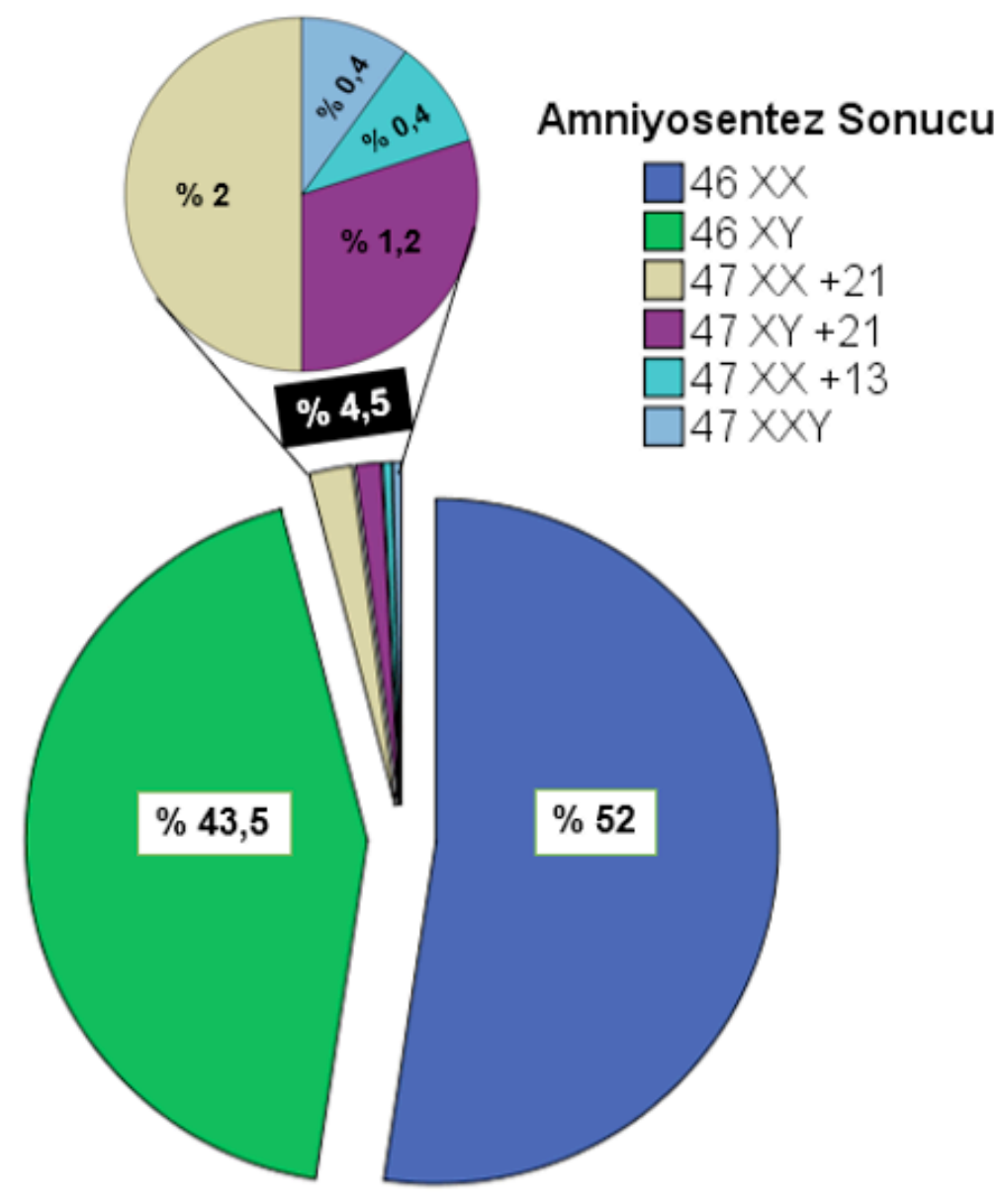

Şekil 2. Olguların amniyosentez sonuçları

Tablo 3. Amniyosentez endikasyonu oluşturan risk faktörlerinin değerlendirilmesi

\begin{tabular}{llllllll}
\hline & $\begin{array}{l}\text { 1. trimester } \\
\text { kombine } \\
\text { testinde risk }\end{array}$ & $\begin{array}{l}\text { 3'lü }_{\text {taramada }} \\
\text { risk }\end{array}$ & $\begin{array}{l}\text { 4'lü } \\
\text { taramada } \\
\text { risk }\end{array}$ & $\begin{array}{l}\text { Anormal } \\
\text { USG } \\
\text { bulgusu }\end{array}$ & $\begin{array}{l}\text { İleri anne } \\
\text { yaşı }\end{array}$ & Diğer & p \\
\hline Hasta sayıSı, $\mathrm{n}(\%)$ & $146(59,3)$ & $39(15,8)$ & $14(5,6)$ & $24(9,7)$ & $6(2,4)$ & $17(6,9)$ & \\
Anormal sonuç, $\mathrm{n}\left(\%^{\mathrm{a}}-\%^{\mathrm{b}}\right)$ & $7(70-4,7)$ & $1(10-2,5)$ & $1(10-7,1)$ & $1(10-4,1)$ & 0 & 0 & 0,756 \\
Yaş, ortanca (IQR) & $36(7)$ & $33(7)$ & $35,5(9)$ & $27(8)$ & $39,5(3)$ & $28(8)$ & $<0,001$ \\
GH, ortanca (IQR) & $17(2)$ & $19(2)$ & $18(2,25)$ & $19,5(4)$ & $16(0,25)$ & $17(2)$ & $<0,001$ \\
Gravide, ortanca (IQR) & $3(2)$ & $3(2)$ & $2(1)$ & $2(3)$ & $2(1)$ & $3(2)$ & 0,062 \\
Parite, ortanca (IQR) & $1(1)$ & $1(1)$ & $1(0)$ & $1(1)$ & $1(1)$ & $2(2)$ & 0,062 \\
\hline
\end{tabular}

IQR: Çeyrekler arası aralık, GH: Gebelik haftası

"\%" anormal sonuçlardaki yüzdeleri; "\%" her bir risk faktöründeki yüzdeleri ifade etmektedir.

Olgularımızın kan grubu, önceki doğum şekilleri, endikasyon oluşturan risk faktörleri, yaş, gebelik haftası, gravide, parite, abortus sayısı çalışmamızın amacıyla uygun olarak amniyosentez sonuçları ile karşılaştırılarak değerlendirildi. Tüm amniyosentez sonuçları, anormal ile normal amniyosentez sonuçları, anormal amniyosentez sonuçları ayrı ayrı değerlendirildi.
Amniyosentez endikasyonu oluşturan risk faktörlerinin olguların yaş ve gebelik haftası değerlerinde gruplar arası anlamlı fark saptandı $(p<0,001)$ (Tablo 3). Post hoc analizi sonrası değerlendirildiğinde ileri anne yaşı ile $3^{\prime} l u ̈$, 4'lü taramada risk, USG'de anomali olması; 1. trimester kombine testinde risk ile 3'lü, 4'lü taramada risk, USG'de anomali olması grupları arasında gebelik haftası açısından anlamlı fark 
varken, USG'de anomali olması ile maternal tarama testlerinde anormallikler ve ileri anne yaşı grupları arasında yaş açısından anlamlı fark vardı $(p<0,001)$.

Kromozomal anomali saptanan olgularda ortanca anne yaşı $34 \quad(I Q R=8)$, ortanca gebelik haftası $18(\mathrm{IQR}=3)$, ortanca gravide 2,5 (IQR=2), ortanca parite ise $1(\mathrm{IQR}=1)$ idi. Amniyosentez sonucu normal ve anormal olarak gruplandırıldığında olguların demografik verilerinde anlamlı fark saptanmadı $(p>0,05)$.

Amniyosentez endikasyonu olarak tarama testlerinde anormallik ve diğerleri olarak gruplandırıldığında amniyosentezin gerçekleştirildiği gebelik haftasında gruplar arasında anlamlı fark saptandı $(p<0,001)$. Post hoc analizi sonrası 18. gestasyonel haftasında amniyosentez yapılanlarda anormal tarama testi sonucu anlamlı olarak daha fazla saptandı.

Amniyosentez sonuçları anormal/ normal, trizomi 21/diğerleri ve ayrı ayrı değerlendirildiğinde tüm bağımsız değişken incelemelerinde gruplar arasında anlamlı fark saptanmadı $(p>0,05)$.

\section{Tartışma}

Son yıllarda prenatal tarama testlerinin yaygınlaşması neticesinde genetik AS işleminin en sık endikasyonunu anormal maternal tarama testleri oluşturmaktadır [5, 6]. Odabaşı ve ark. [7] derlemelerinde AS endikasyonu olarak ileri anne yaşını kendi çalışmaları dahil 10 araştırmada, anormal üçlü tarama testi ise 6 araştırmada bildirdiler. Çalışmamızdaki hastaların \%80,9'una anormal maternal tarama testleri nedeniyle AS işlemi uygulanmış, bunlardan da en sık \%59,3 ile ikili tarama testi endikasyon oluşturmuştur.

Genetik AS'de saptanan kromozomal anomali sıkı̆̆ı çeşitli çalışmalarda \%1,5 ile $\% 14,3$ arasında değişen oranlarda saptanmıştır. Çalışmamızda olguların \%4,5'inde AS anormal sonuçlanmış, bunlardan da en sık olarak 10 olgudan 8'inde Trizomi 21 saptanmıştır. Çalışmamızla benzer olarak ülkemizde yapılan 17 çalışmada en sık anomali olarak Trizomi 21 saptanırken, 2 çalışmada Edwards, birer çalışmada Turner ve Klinefelter, bir çalışmada da Trizomi 21, Turner ve Klinefelter aynı oranda saptandığı bildirilmiştir [8].
İleri anne yaşı endikasyonu ile saptanan anormal AS sonucu Odabaşı ve ark. [7] çalışmasında $\% 40$ iken derledikleri diğer çalışmalarda \%0-80 arasında değişen oranlarda saptanmış. Çalışmamızda maternal tarama testi yaptırmadan yalnızca ileri anne yaşı endikasyonu ile saptanan anormal AS sonucu olmazken, 4 olguda (\%40) anormal maternal tarama testi ile birlikte ileri anne yaşı olup anormal karyotipte (2 olgu Trizomi 21, 1 olgu 47 $X X Y, 1$ olgu $47 X X+13$ ) sonuçlanmıştır. Singh ve ark. [9] ise hem ileri anne yaşı olup hem de anormal 3'lü tarama testi olan olgularda Trizomi 21 duyarlıı̆ını \%92,3 (\%0,8 hata) olarak saptamışlardır. Çalışmamızda ise hem ileri anne yaşı olup hem de anormal 3'lü tarama testi olan 15 olguda anormal AS sonucu saptanmadı.

Çalışmamızda anormal USG bulgusu endikasyonu ile uygulanan AS'de anormal karyotip (Trizomi 21) yalnızca 1 olguda saptanmış olup bu değer, anormal karyotip olgularının \%10'nunu oluşturmaktadır. Viora ve ark. [10] çalışmasında anormal USG bulguları endikasyonu ile uygulanan AS'de normal karyotip sonuçlanan olgularda \%28, Trizomi 21 sonuçlanan olgularda ise $\% 70$ ile bildirirlerken, diğer çalışmalarda [11-13] \%6 ile 28 arasında değişen oranlarda saptanmıştır.

Prenatal invazif testlerin amacı genellikle trizomi 21 gibi spesifik kromozomal anormalliklerin araştırılmasına yöneliktir. Günümüzde tüm çabalar kromozomal anomalilerin amniyosentez kullanılarak prenatal tanısından ziyade amniyosentez sayısını azaltacak etkili prenatal tarama programları kullanımına yönelmiştir.

Sonuç olarak çalışmamızda kromozom anomalisi oranını $\% 4,5$ olarak bulduk. En sık amniyosentez endikasyonumuz maternal 1 . trimester kombine testinde anormallik $(\% 59,3)$ idi. Çalışmanın limitasyonları arasında, uygulanan işlem sonrası erken ve geç dönem komplikasyon verilerine yeterince ulaşılamaması sayılabilir. Genetik ve prenatal tanı uygulanan kliniğimizde gerçekleştirdiğimiz tek merkezli bu serinin gelecekte yapılacak özellikle çok merkezli geniş vaka seri çalışmalarına büyük katkı sağlayacağını düşünmekteyiz.

Çıkar ilişkisi: Yazarlar çıkar ilişkilerinin olmadığını beyan ederler. 


\section{Kaynaklar}

1. Beksaç MS. Fetal tıp prenatal tanı. Ankara: Medical Network \& Nobel, 1996:29-38.

2. Platt LD, DeVore GR, Lopez E, Herbert W, Falk R, Alfi O. Role of amniocentesis in ultrasound detected fetal malformations. Obstet Gynecol 1986;68:153-155.

3. Blackwell SC, Abundis MG, Nehra PC. Five year experience with midtrimester amniocentesis performed by a single group of obstetriciangynecologists at a community hospital. Am J Obstet Gynecol 2002;186:130-132. https://doi.org/10.1067/ mob.2002.122987

4. American College of Obstetricians and Gynecologists' Committee on Practice Bulletins-Obstetrics, Committee on Genetics, \& Society for Maternal-Fetal Medicine. Practice Bulletin No. 162: Prenatal Diagnostic Testing for Genetic Disorders. Obstetrics and gynecology, 2016;127:108-122. https://doi.org/10.1097/ AOG.0000000000001405

5. Turhan Öztürk N, Eren Ü, Seçkin NC. Second trimester genetic amniocentesis: 5 year experience. Arch Gynecol Obstet 2005;271:19-21. https://doi. org/10.1007/s00404-004-0635-9

6. Türkyılmaz A, Budak T. Laboratuvarımıza prenatal tanı için sevk edilen ailelerde endikasyon ve sonuç uygunluklarının değerlendirilmesi. Dicle Tıp Dergisi 2007;34:258-263.

7. Odabaşı A, Yüksel H, Sezer Demircan S, ve ark. İkinci trimester genetik amniyosentez işleminin sonuçları: Türkiye'deki 22 merkezin sonuçlarıyla birlikte, Adnan Menderes Üniversitesi deneyimi. Türkiye Klinikleri J Gynecol Obst 2007;17:196-206.

8. Acar A, Ercan F, Yıldırım S, ve ark. Genetik amniyosentez sonuçlarımız: 3721 vakanın analizi. 2016. Şişli Etfal Hastanesi Tıp Bülteni. 2016;50:33-38. https://doi.org/10.5350/semb.20160103093300

9. Bahado Singh R, Shahabi S, Karaca M, et al. The comprehensive midtrimester test: high-sensitivity Down syndrome test. Am J Obstet Gynecol 2002;186:803808. https://doi.org/10.1067/mob.2002.121651

10. Viora E, Errante G, Bastonero S, et al. Minor sonographic signs of trisomy 21 at $15-20$ weeks' gestation in fetuses born with out malformations: a prospective study. Prenat Diagn 2001;21:1163-1166. https://doi.org/10.1002/pd.197

11. Rizzo N, Pittalis MC, Pilu G, Orsini LF, Perolo A, Bovicelli L. Prenatal karyotyping in malformed fetuses. Prenat Diagn 1990;10:17-23. https://doi.org/10.1002/ pd.1970100104

12. Dallaire L, Michaud J, Melancon SB, et al. Prenatal diagnosis of fetal anomalies during the second trimester of pregnancy: their characterization and delineation of defects in pregnancies at risk. Prenat Diagn 1991;11:629-635. https://doi.org/10.1002/ pd. 1970110821
13. Stoll C, Dott B, Alembik $Y$, et al. Evalution of routine prenatal ultrasound examination in detecting fetal chromosomal abnormalities in a low risk population. Hum Genet 1993;91:37-41. https://doi.org/10.1007/ BF00230219

Etik kurul onayı: Bu çalışma, Pamukkale Üniversitesi Girişimsel Olmayan Araştırmalar Etik Kurulu'nun 09.06.2020 tarih ve 11 sayılı kurul toplantısında görüşülerek etik açıdan sakınca olmadığına karar verilmiştir.

\section{Yazarların makaleye olan katkıları}

S.G. ve B.C.G. çalışmanın ana fikrini ve hipotezini kurgulamışlardır. G.O.Ç. teoriyi geliştirmiş ve materyel metod bölümünü düzenlemiş/düzenlemişlerdir. Sonuçlar kısmınındaki verilerin değerlendirmesini S.G. ve B.C.G. yapmışlardır. Makalenin tartışma bölümü S.G. tarafından yazıımış, B.C.G. gözden geçirip gerekli düzeltmeleri yapmış ve onaylamıştır. Ayrıca tüm yazarlar çalışmanın tamamını tartışmış ve son halini onaylamıştır. 